\title{
Factors Affecting Sleep Hygiene Training of Nursing Students
}

\section{Hemșirelik Öğrencilerinin Uyku Hijyeni Öğretimini Etkileyen Faktörler}

\author{
(1) Elif Günay İsmailoğlu, (1 Handan Özdemir* \\ Izmir Bakırçay University Faculty of Health Sciences, Department of Nursing, Izmir, Turkey \\ *Burdur Mehmet Akif Ersoy University Faculty of Health Sciences, Department of Nursing, Burdur, Turkey
}

\begin{abstract}
Objective: As a part of their clinical practice curriculum, nursing students are expected to provide sleep hygiene (SH) training to their patients. It is important to determine the factors that affect this training program. We aimed to examine the nursing students' condition of delivering $\mathrm{SH}$ training to their patients as well as the relationship between the training program and the students' SH behaviors, knowledge of sleep, and attitude toward the training program.

Materials and Methods: A total of 259 nursing students in their second year of bachelor's degree education participated in this study. The data were gathered by using the Individual Identification Form, SH index, Sleep Knowledge Assessment form, and Attitude Towards SH Training form.

Results: Based on analysis of the data gathered from the forms, all students reported having received $\mathrm{SH}$ training and $80.3 \%$ of them admitted to delivering the training to their patients. Logistic regression analysis of the data revealed that $\mathrm{SH}$ (Wald $\chi 2=7.01, \mathrm{p}=0.008$ ), knowledge of sleep (Wald $\chi 2=15.63, p<0.001$ ), and the attitude toward $\mathrm{SH}$ training (Wald $\chi 2=36.29, \mathrm{p}<0.001$ ) are important determinants of $\mathrm{SH}$ training.

Conclusion: The results of this study suggest that better sleep hygiene, enhanced information on sleep, and more positive attitude toward SH training increases the likelihood of successful delivery of SH training to patients.
\end{abstract}

Keywords: Nursing student, Sleep hygiene training, Patient education
Öz

Amaç: Klinik uygulamada, hemşirelik öğrencilerinden hastalarına uyku hijyeni (UH) eğitimi vermeleri beklenmektedir. Burada öğrencinin hastaya yönelik yaptığı UH öğretimini etkileyen faktörlerin ne olduğunun belirlenmesi önemlidir. Araştırmanın amacı, hemşirelik öğrencilerinin hastalarına UH eğitimi verme durumu ve UH öğretimi ile UH davranışı, uyku bilgisi ve UH öğretimine ilişkin tutumları arasındaki ilişkiyi incelemektir.

Gereç ve Yöntem: Araştırma ikinci sınıfta öğrenim gören 259 hemşirelik öğrencisi ile yürütüldü. Veriler, Birey Tanıtım Formu, UH indeksi, Uyku Bilgisi Değerlendirme formu ve UH Öğretimine Yönelik Tutum formu kullanılarak toplandı.

Bulgular: Öğrencilerin tamamı UH ile ilgili eğitim aldıklarını ve \%80,3'ü hastalarına uyku eğitimi verdiğini belirtmiştir. Lojistik regresyon analizi sonuçlarına göre, $\mathrm{UH}$ (Wald $\chi 2=8,07, \mathrm{p}=0,004$ ), uyku bilgisi (Wald $\chi 2=43,24, p=0,000$ ) ve UH öğretimine yönelik tutum (Wald $\chi 2=7,24$, $\mathrm{p}=0,007) \mathrm{UH}$ öğretiminin önemli belirleyicileri olduğu bulunmuştur.

Sonuç: Araştırma sonucunda, daha iyi UH, uyku hakkında daha fazla bilgi ve UH öğretimine yönelik daha olumlu tutumların hastalara $\mathrm{UH}$ öğretimi verme olasılığını arttırdığı saptanmıştır.

Anahtar Kelimeler: Hemşirleik öğrencisi, Uyku hijyen eğitimi, Hasta eğitimi

\section{Introduction}

Sleep, which is one of the basic needs, is a major variable of health affecting individuals' quality of life. Sleep is effective in maintaining normal thermoregulation, strengthening the immune system, and helping brain development as well as somatic growth and development $(1,2)$. Regular and highquality sleep increases the ability of reasoning; thus, the ability to make decisions and learn new information (3).
Many factors affect the quality and quantity of sleep, which is one of the requirements of a healthy life. Many studies demonstrate that patients have low sleep quality and experience a higher number of sleep disorders (4-7). Sleep disorders in patients cause adverse conditions such as delayed healing, pain, anxiety, increased risk of falling, and physical-mental health problems $(4,8)$. Due to such problems, it is necessary to provide a suitable environment for the hospitalized patients to sleep comfortably.

Address for Correspondence/Yazışma Adresi: Elif Günay İsmailoğlu PhD, İzmir Bakırçay University Faculty of Health Sciences, Department of Nursing, İzmir, Turkey Phone: +90 2324931241 E-mail: elif.ismailoglu@bakircay.edu.tr ORCID-ID: orcid.org/0000-0002-9152-3469 Received/Geliş Tarihi: 08.06.2020 Accepted/Kabul Tarihi: 16.08.2020

${ }^{\circ}$ Copyright 2020 by Turkish Sleep Medicine Society / Journal of Turkish Sleep Medicine published by Galenos Publishing House. 
Meeting the physiological needs of patients is one of the major functions of nurses, who follow a holistic approach. Since sleep is a physiological requirement, it is important for nurses to identify and eliminate the conditions that impede patients sleeping comfortably (9). Furthermore, informing patients of sleep hygiene $(\mathrm{SH})$ is one of the responsibilities of nurses regarding sleep (1). SH is comprised of principles and practices that improve sleep quality (10). The scope of the SH training covers topics such as the regulation of sleep environment, sleep time, nutrient intake, daily activities and mental control (11). SH training designed for patients helps them reduce or eliminate sleep problems $(12,13)$.

It is important for nurses who provide $\mathrm{SH}$ training to their patients to behave in accordance with $\mathrm{SH}$ and have information about sleep in order to improve sleep quality. Knowledge of sleep physiology and the factors acting on it is a prerequisite to providing the necessary care regarding sleep. The attitude towards a certain behavior creates more desire to demonstrate that particular behavior. Nurses who believe in and adopt healthy behaviors are more likely to serve as positive role models for their patients through patient training. For this reason, exhibiting appropriate $\mathrm{SH}$ behaviors, having information about sleep and a positive attitude towards sleep training are considered to be factors affecting SH training $(14,15)$.

Acquisition of the things to be done for patients with sleep problems in nursing is expected to take place throughout the training process. In this process, students are expected to undertake interventions for patients with sleep problems during their clinical internships. Among these interventions, the most common is observed to be students' informing patients of SH. At this point, it is crucial to determine the factors affecting $\mathrm{SH}$ training students deliver to patients. In this study, the relationship between the $\mathrm{SH}$ training nursing students deliver to their patients and their SH behaviors, knowledge of sleep, and attitudes towards $\mathrm{SH}$ training will be investigated.

Aim and type of research: The research was conducted as a descriptive study to examine the nursing students' condition of delivering $\mathrm{SH}$ training to their patients as well as the relationship between the $\mathrm{SH}$ training and their SH behaviors, knowledge of sleep, and attitudes towards SH training.

\section{Materials and Methods}

\section{Participants}

The population of the research was comprised of $2^{\text {nd }}$ grade students $(n=270)$ studying at the Nursing Department of two public universities in the 2019-2020 academic year. A sample selection was not made and 259 students from the population who accepted to participate in the study constituted the sample. The sociodemographic characteristics of the participants were shown in Table 1.

\section{Measures}

Participants were asked to complete Individual Identification Form, SH index (SHI), Sleep Knowledge Assessment form (SKAF) and Attitude Towards SH Training form (ATSHTF).
Individual Identification form: It is comprised of questions to determine the sociodemographic characteristics of nursing students. In addition, the form also includes items that question the students' condition of delivering $\mathrm{SH}$ training to their patients with sleep problems, the scope of the training, and the barriers of those who do not deliver the training.

SH index: It was developed by Mastin et al. in 2006, and its Turkish validity and reliability was conducted by Özdemir et al. (16) in 2015. The index consists of 13 questions that determine the frequency of engaging in $\mathrm{SH}$ behaviors. The total score of the index, which is a 5-point Likert type (1: never, 2: rarely, 3: sometimes, 4: frequently, 5: always) ranges between 13-65. Higher scores are indicative of a poor SH condition. The Cronbach alpha coefficient of the index was found to be 0.70 (16).

Sleep Knowledge Assessment form: It is a form prepared by the researchers to determine the students' level of knowledge regarding sleep. The form consists of 10 (ten) closed-ended questions that evaluate the students' knowledge regarding sleep physiology, factors affecting sleep and $\mathrm{SH}$. Each question has two options; "true" or "false". The total score to be taken ranges between 0-10. At the end of the assessment, it is determined that a higher score indicates a higher level of knowledge regarding sleep. Before the implementation, the questions in the test were evaluated and finalized by 4 educators who are experts in the field.

Attitude Towards Sleep Hygiene Training form: It is a form developed by the researcher to determine students' attitudes towards SH training. The form consists of 9 questions that students will answer themselves. The total score of the 5-point Likert-type test (1: strongly disagree - 5: strongly agree) ranges between 9 and 45. It is determined that as students get higher points from the total of the test, they develop a positive attitude towards SH training. The questions in the test were evaluated and finalized by 4 educators who are experts in the field.

The pre-test of the research was conducted with 10 students who were not included in the sample. The results of the pretest confirmed the comprehensibility of the SKAF and ATSHTF.

\section{Procedure}

Written informed consents were obtained from the students who volunteered to participate in the research before the application of the forms. The students were asked to fill in the forms anonymously and the application took approximately 15-20 minutes.

\section{Ethical Consideration}

Written consent was obtained from Özdemir, who conducted the validity and reliability of SHI used in the research. Written consent was obtained from the Scientific Research and Publication Ethics Committee (2019/166) of a university and the institutions where the research will be conducted for the implementation of the research. The students included in the research were informed about the research prior to the research and their written informed consents were obtained. 


\section{Statistical Analysis}

The data collected in the research were analyzed with The Package for Social Sciences (SPSS) 20 using number, percent. Factors affecting the probability of students delivering $\mathrm{SH}$ training were determined by logistic regression analysis. The independent sample t-test was used to assess the difference between SHI, SKAF and ATSHTF total mean scores by delivering sleep training to patient.

\section{Results}

The mean age of the students was $21.32 \pm 2.37$ years of which $73.7 \%$ were female and $95.8 \%$ were single. All of the students stated that they received education about sleep and $80.3 \%$ stated that they delivered sleep training to their patients. Of those who delivered sleep training, $72.7 \%$ stated that the training content was related to "organizing pre-sleep activities" (Table 1).

Students' SHI, SKAF and the ATSHTF total mean scores were $26.12 \pm 5.48,8.16 \pm 1.11$ and $38.08 \pm 3.69$ points, respectively. According to students' condition of delivering training, there was no statistically significant difference between $\mathrm{SHI}$ total mean score $(t=1.604, p=0.110)$; however, a significant difference was found between the mean scores of SKAF $(t=11.424, p=0.000)$ and ATSHTF ( $t=5.697, p=0.000)$. Accordingly, it was found that the students who delivered SH training to their patients had higher scores of sleep knowledge and attitude towards $\mathrm{SH}$ training (Table 2).

Table 3 shows the results of the logistic regression analysis performed to examine the determinants of students' $\mathrm{SH}$ training. Accordingly, it was determined that $\mathrm{SH}$ behaviors, knowledge of sleep and attitudes towards $\mathrm{SH}$ training were effective factors in students' condition of delivering $\mathrm{SH}$ training. The regression model revealed that better $\mathrm{SH}$ [odds ratio $(\mathrm{OR})=1.128,95 \%$ confidence interval $(\mathrm{Cl})(1.04,1.23)]$, more information on sleep $(\mathrm{OR}=6.638,95 \% \mathrm{Cl}[3.78,11.67])$ and more positive attitudes towards training (OR=1.163, 95\%
$\mathrm{Cl}[1.04,1.3])$ increased the likelihood of the delivery of $\mathrm{SH}$ training to patients. In addition, the correct classification rate of the binary logistic regression model is determined as $89.2 \%$.

\section{Discussion}

According to the mean scores the participating students received from the $\mathrm{SHI}(26.12 \pm 5.48)$, it can be concluded that they demonstrate $\mathrm{SH}$ behaviors at a moderate level. In the study conducted by Odabaşığlu et al. (17), the mean SHI score of the students was found to be 33 . It has been determined (10) that the majority of students had poor SH. In another study, it was found that $\mathrm{SH}$ awareness was significantly worse

\begin{tabular}{|c|c|c|c|}
\hline & & $\mathbf{n}$ & $\%$ \\
\hline Age (mean $\pm S D)$ & $21.32 \pm 2.37$ & & \\
\hline \multirow{2}{*}{ Sex } & Female & 191 & 73.7 \\
\hline & Male & 68 & 26.3 \\
\hline \multirow{2}{*}{ Marital status } & Single & 248 & 95.8 \\
\hline & Married & 11 & 4.2 \\
\hline \multirow{2}{*}{$\begin{array}{l}\text { Received sleep } \\
\text { hygiene education }\end{array}$} & Yes & 259 & 100 \\
\hline & No & - & - \\
\hline \multirow{2}{*}{$\begin{array}{l}\text { Delivered sleep } \\
\text { training to patient }\end{array}$} & Yes & 208 & 80.3 \\
\hline & No & 51 & 19.7 \\
\hline \multirow{2}{*}{$\begin{array}{l}\text { Sleep training } \\
\text { content }(n=208)\end{array}$} & Cause of sleep problems & 57 & 27.3 \\
\hline & $\begin{array}{l}\text { Organizing } \\
\text { pre-sleep activities }\end{array}$ & 151 & 72.7 \\
\hline \multirow{3}{*}{$\begin{array}{l}\text { Reason for not } \\
\text { delivering } \\
\text { sleep training }(n=51)\end{array}$} & Lack of time & 34 & 66.7 \\
\hline & $\begin{array}{l}\text { Not knowing the } \\
\text { training } \\
\text { content enough }\end{array}$ & 14 & 27.5 \\
\hline & $\begin{array}{l}\text { No patient with } \\
\text { sleep problems }\end{array}$ & 3 & 5.9 \\
\hline \multicolumn{4}{|l|}{ SD: Standard deviation } \\
\hline
\end{tabular}

Table 2. Sleep hygiene, sleep knowledge and attitude towards sleep hygiene training mean scores of students

\begin{tabular}{|l|l|l|l|l|l|l|l|}
\hline & $\mathbf{n}$ & $\mathbf{M} \pm$ SD & Min-max & Delivered sleep training to patient & $\mathbf{t}$ & $\mathbf{p}$ \\
\hline & & & & Yes (208) & No (51) & & \\
\hline SHI & 259 & $26.12 \pm 5.48$ & $13-45$ & $26.39 \pm 5.56$ & $25.02 \pm 5.06$ & 1.604 & 0.110 \\
\hline SKAF & 259 & $8.16 \pm 1.11$ & $4-10$ & $8.48 \pm .83$ & $6.86 \pm 1.17$ & $\mathbf{1 1 . 4 2 4}$ & $\mathbf{0 . 0 0 0}$ \\
\hline ATSHTF & 259 & $38.08 \pm 3.69$ & $16-43$ & $38.69 \pm 2.69$ & $35.59 \pm 5.68$ & 5.697 & $\mathbf{0 . 0 0 0}$ \\
\hline
\end{tabular}

M: Mean, SD: Standard deviation, t: Independent sample t-test, SHI: Sleep Hygiene index, SKAF: Sleep Knowledge Assessment form, ATSHTF: Attitude Towards Sleep Hygiene Training form, min: Minimum, max: Maximum

\begin{tabular}{|l|}
\hline Table 3. Factors affecting the probability of students delivering sleep hygiene training \\
\hline Logistic regression analysis $(\mathbf{n = 2 5 9 )}$ \\
\hline
\end{tabular}


in young adults (18). The transition to university is the period when students stay on their own for the first time and the transition from adolescence to adulthood also begins $(19,20)$. Sleep disorders are more common among university students than non-students in the same age group (21). Jiang et al. (22) stated that the prevalence of composite insomnia among university students was $18.5 \%$. In a study conducted with 7000 university students, $62 \%$ of students were reported to have poor sleeping habits (23). SH behaviors are one of the important variables that affect sleep habits. In the literature, it is stated that the irregular life cycles of nursing students are significant obstacles for sleep (24). The fact that the students included in the study were in the theoretical part of their education and in the internship period may have caused them not to be able to perform high SH behaviors. Furthermore, it is known that there is a relationship between SH behaviors and sleep quality (25). In some studies, it was determined that the university students who had poor SH had low sleep quality $(20,25,26)$. In our study, the sleep quality of students was not directly evaluated. However, based on this information, it could be argued that it is essential for nursing students to demonstrate appropriate $\mathrm{SH}$ behaviors for better sleep quality. In addition, it can be put forward that acquisition of appropriate $\mathrm{SH}$ behaviors is an important determinant for students in terms of both preventing depressive symptoms and providing self-management as future nurses as well as being able to work longer and healthier in the long term (24).

Sleep in hospital has been defined as a stressor for many patients (4-7). During hospitalization, patients experience more sleep problems compared to their sleep patterns at home $(5,6)$. It is reported in the literature that sleep, which is mentioned as a deprioritized and overlooked topic, not only has positive effects on the immune system and inflammatory processes, but also increases patients' ability to get involved in their own care (4). Supporting sleep in a hospital environment is important for nursing care. Nurses play a very important role in initiating and implementing interventions which can improve the sleep quality of patients $(8,15)$. In a study conducted with psychiatric patients, it was revealed that sleep disorder was significantly reduced thanks to appropriate nursing interventions (27). Informing patients is the prioritized item on the list of activities that support sleep. It was conducted (27), a positive increase was observed in the sleep quality of patients after sleep training. Informing patients will provide the relaxation they need and help them meet their sleep needs (28). The scope of the informing process generally covers training. $\mathrm{SH}$ training is a health-promoting behavior between caregivers and patients (29-31). Throughout their clinical education, nursing students are also expected to plan and implement the necessary nursing interventions for patients suffering from sleep problems. In this study, the majority of the students $(80.3 \%)$ stated that they delivered training to their patients adding that the content of the training included informing the patients regarding the organization of pre-sleep activities. In addition, almost all of the students in our study stated that SH training was the most appropriate intervention to increase the sleep quality of patients and they believed that it would be effective. Furthermore, the fact that the students received a high total score of attitude towards training shows that they attach importance to sleep training.

Another significant point is that students should have information about sleep in order to perform nursing interventions related to sleep $(8,15)$. Adequate knowledge of sleep is a prerequisite for nursing students to be able to provide $\mathrm{SH}$ training in patient care independently (15). Research shows that healthcare professionals do not have enough information to support patients' sleep $(4,32,33)$. In a systematic review, it was found that the training on sleep and patient sleep in nursing programs was inadequate and limited (4). In our study, it was determined that the sleep knowledge scores of students were above average. Unlike the findings of our study; in the study of Huang et al. (15), the sleep knowledge scores of students were found to be low. However, it was also stated that this finding could be related with the fact that one third of the students did not receive $\mathrm{SH}$ training. In another study, it was found that students did not have knowledge of sleep physiology. Also, in the same study, the students stated that they did not feel ready to deliver sleep training to their patients with the education they had received (34). It was found (35) that the SH knowledge of university students was inadequate. Furthermore, the studies in question recommend that the topic of sleep be integrated to nursing education. In our study, the theoretical education that all the students received about sleep may have caused them to have adequate sleep knowledge and the majority to deliver sleep training to their patients.

As prospective nurses, students of nursing are responsible for protecting their patients' health in clinical practice. In order to fulfill this responsibility, they must also protect their own health (24). Similarly, in our study, it is expected that students demonstrate appropriate $\mathrm{SH}$ behaviors so that they can support their patients regarding sleep. Nurses who have a more positive attitude towards are more likely to teach it to their patients. As a result of our research, it was determined that behaviors towards, sleep knowledge and attitudes towards training were effective factors regarding students' condition of delivering $\mathrm{SH}$ training. Similar results were obtained in Huang's study (15). Esposito and Fitzpatrick (14) found a link between nurses' sleep quality and teaching behaviors, and revealed that those who adopted healthy behaviors were more likely to be positive role models for their patients in patient training. In a retrospective study, it was found that there was a significant correlation between nurses' sleep deprivation and quality of care (36). In the study conducted by Brown (37), it was determined that having knowledge about was associated with appropriate $\mathrm{SH}$ practices. At this point, it can be concluded that students' level of knowledge, behavior and attitude affect their condition of delivering training. During clinical practice, nursing students are expected to collect data from the patient based on functional health patterns (FHP). Since sleep is an item included in FHP, insufficient level of sleep knowledge and attitude towards will cause students to collect insufficient data from patients. 
Accordingly, it will not be possible to expect students to approach patients in a holistic manner and provide full and quality care.

\section{Conclusion}

As a result of the study carried out with 259 nursing $2^{\text {nd }}$ year students, it was found that the students who delivered $\mathrm{SH}$ training to their patients had higher scores of sleep knowledge and attitude towards $\mathrm{SH}$ training. In line with these results, it is essential that sleep physiology, $\mathrm{SH}$ and management of patients' sleep problems be either included in nursing curriculum or covered independently in lessons. Furthermore, students should be supported by instructors regarding their approach to patients with sleep problems in clinical practice.

\section{Ethics}

Ethics Committee Approval: Written consent was obtained from the Scientific Research and Publication Ethics Committee (2019/166) of a university and the institutions where the research will be conducted for the implementation of the research.

Informed Consent: The students included in the research were informed about the research prior to the research and their written informed consents were obtained.

Peer-review: Internally peer-review.

\section{Authorship Contributions}

Surgical and Medical Practices: E.G.I., H.Ö., Concept: E.G.I., Design: E.G.I., Data Collection or Processing: E.G.I., H.Ö., Analysis or Interpretation: E.G.I., Literature Search: E.G.I., H.Ö., Writing: E.G.I., H.Ö.

Conflict of Interest: This research do not have any conflict of interest and source of funding.

Financial Disclosure: The authors declared that this study received no financial support.

\section{References}

1. Potter P, Perry A, Stockert P, Hall A. Fundamentals of Nursing. 9th ed, Mosby, 2016.

2. Sarı ÖY, Üner S, Büyükakkuş B, Bostancı EÖ, Çeliksöz AH, Budak M. Bir üniversitenin yurtta kalan öğrencilerinde uyku kalitesi ve etkileyen bazı faktörler. TAF Preventive Medicine Bulletin 2015;14:93-100.

3. Rasch B, Born J. About sleep's role in memory. Physiol Rev 2013;93:681-766.

4. Gellerstedt L, Medin J, Kumlin M, Karlsson MR. Sleep as a topic in nursing education programs? A mixed method study of syllabuses and nursing students' perceptions. Nurse Educ Today 2019;79:168-74.

5. Dobing S, Frolova N, McAlister F, Ringrose J. Sleep quality and factors influencing self-reported sleep duration and quality in the general internal medicine inpatient population. PLoS One 2016;11:e0156735.

6. Wesselius HM, van den Ende ES, Alsma J, Ter Maaten JC, Schuit SCE, Stassen PM, de Vries OJ, Kaasjager KHAH, Haak HR, van Doormaal FF, Hoogerwerf JJ, Terwee CB, van de Ven PM, Bosch FH, van Someren EJW, Nanayakkara PWB; "Onderzoeks Consortium Acute Geneeskunde" Acute Medicine Research Consortium. Quality and quantity of sleep and factors associated with sleep disturbance in hospitalized patients. JAMA Intern Med 2018;178:1201-8.
7. Delaney LI, Currie MJ, Huang HC, Lopez V, Van Haren F. They can rest at home: an observational study of patients' quality of sleep in an Australian hospital. BMC Health Serv Res 2018;18:524.

8. Pilkington S. Causes and consequences of sleep deprivation in hospitalised patients. Nurs Stand 2013;27:35-42.

9. Batmaz I, Sarıyıldız MA, Dilek B, Bez Y, Karakoç M, Çevik R. Sleep quality and associated factors in ankylosing spondylitis: Relation with disease parameters, psychological status and quality of life. Ann Rheum Dis 2013;71(Suppl 3):690.

10. Kaur $\mathrm{G}$, Singh A. Excessive daytime sleepiness and its pattern among Indian college students. Sleep Med 2017;29:23-8.

11. Güneş Z. Uyku Sağlığının Korunmasında Uyku Hijyenin Rolü ve Stratejileri. Arşiv Kaynak Tarama Dergisi 2018; 27(2):188-198.

12. Bonnet MH and Arand DL. Treatment of insomnia. Available at: http:// www.uptodate.com/contents/treatment-of-insomnia (accessed 15 May 2020)

13. Wong MM, Puttler LI, Nigg JT, Zucker RA. Sleep and behavioral control in earlier life predicted resilience in young adulthood: A prospective study of children of alcoholics and controls. Addict Behav 2018;82:65-71.

14. Esposito EM, Fitzpatrick JJ. Registered nurses' beliefs of the benefits of exercise, their exercise behaviour and their patient teaching regarding exercise. Int J Nurs Pract 2011;17:351-6.

15. Huang CY, Liao HY, Chang ET, Lai HL. Factors associated with the teaching of sleep hygiene to patients in nursing students. Nurse Educ Pract 2018;28:150-5.

16. Özdemir PG, Boysan M, Selvi Y, Yildirim A, Yilmaz E. Psychometric properties of the Turkish version of the sleep hygiene index in clinical and non-clinical samples. Compr Psychiatry 2015;59:135-40.

17. Odabaşığlu ME, Dedeoğlu T, Kasırga Z, Sünbül F. Üniversite Öğrencilerinde Uyku Hijyeni. Gümüşhane Üniversity J of Health Sciences 2017;6:204-12.

18. Voinescu BI, Szentagotai-Tatar A. Sleep hygiene awareness: its relation to sleep quality and diurnal preference. J Mol Psychiatry 2015;3:1-7.

19. Gipson CS, Chilton JM, Dickerson SS, Alfred D, Haas BK. Effects of a sleep hygiene text message intervention on sleep in college students. J Am Coll Health 2019;67:32-41.

20. Li L, Lok KI, Mei SL, Cui XL, Li L, Ng CH, Ungvari GS, Ning YP, An FR, Xiang YT. Sleep duration and self-rated health in Chinese university students. Sleep Breath 2019;23:1351-6.

21. ivertsen B, Vedaa $\varnothing$, Harvey AG, Glozier N, Pallesen S, Aarø LE, Lønning KJ, Hysing M. Sleep patterns and insomnia in young adults: A national survey of Norwegian university students. J Sleep Res 2019;28:e12790.

22. Jiang XL, Zheng XY, Yang J, Ye CP, Chen YY, Zhang ZG, Xiao ZJ. A systematic review of studies on the prevalence of insomnia in university students. Public Health 2015;129:1579-84.

23. Becker SP, Jarrett MA, Luebbe AM, Garner AA, Burns GL, Kofler MJ. Sleep in a large, multi-university sample of college students: sleep problem prevalence, sex differences, and mental health correlates. Sleep Health 2018;4:174-81.

24. Park E, Lee HY, Park CSY. Association between sleep quality and nurse productivity among Korean clinical nurses. J Nurs Manag 2018;26:1051-8.

25. Yazdi Z, Loukzadeh Z, Moghaddam P, Jalilolghadr S. Sleep hygiene practices and their relation to sleep quality in medical students of Qazvin University of Medical Sciences. J Caring Sci 2016;5:153-60.

26. Kabrita CS, Hajjar-Muça TA, Duffy JF. Predictors of poor sleep quality among Lebanese university students: association between evening typology, lifestyle behaviors, and sleep habits. Nat Sci Sleep 2014;6:11-8. 
27. Uğurlu N, Kostakoğlu N, Ağca D, Tekin L. Psikiyatri hastalarının uyku hijyeni eğitimi öncesi ve sonrası uyku durumlarının belirlenmesi. J Psychiatric Nurs 2018;9:23-8.

28. Demir AU, Ardic S, Fırat H, Karadeniz D, Aksu M, Ucar ZZ, Peker Y, Aygül F, Kıran S, Gelbal S, Çepni Z, Akozer M; Tapes Investigation Committee. Prevalence of sleep disorders in the Turkish adult population epidemiology of sleep study. Sleep and Biological Rhythms 2015;13:298-308.

29. Vanhuffel H, Rey M, Lambert I, Da Fonseca D, Bat-Pitault F. Contribution of mindfulness meditation in cognitive behavioral therapy for insomnia. Encephale 2018;44:134-40.

30. Şahin EM, Öztürk L, Oyekcin DG, Uludağ A. Effects of sleep hygiene education on subjective sleep quality and academic performance. Journal of Clinical and Analytical Medicine 2016;7:304-8.

31. Todd J, Mullan B. The role of self-regulation in predicting sleep hygiene in university students. Psychol Health Med 2013;18:275-88.
32. Hopper K, Fried TR, Pisani MA. Health care worker attitudes and identified barriers to patient sleep in the medical intensive care unit. Heart Lung 2015;44:95-9.

33. Radtke K, Obermann K, Teymer L. Nursing knowledge of physiological and psychological outcomes related to patient sleep deprivation in the acute care setting. Medsurg Nurs 2014;23:178-84.

34. Mclntosh AE, MacMillan M. The knowledge and educational experiences of student nurses regarding sleep promotion in hospitals. Nurse Educ Today 2009;29:796-800.

35. Al-Kandari S, Alsalem A, Al-Mutairi S, Al-Lumai D, Dawoud A, Moussa $M$. Association between sleep hygiene awareness and practice with sleep quality among Kuwait University students. Sleep Health 2017;3:342-7.

36. Stimpfel AW, Fatehi F, Kovner C. Nurses' sleep, work hours, and patient care quality, and safety. Sleep Health 2020;6:314-20.

37. Brown FC, Buboltz WC Jr, Soper B. Relationship of sleep hygiene awareness, sleep hygiene practices, and sleep quality in university students. Behav Med 2002;28:33-8. 